\title{
Some Issues of Financial Stability Analysis
}

\section{Lombodorj Naranchimeg, Ch. Enkhamgalan}

Accounting Department, Business School, National University of Mongolia, Ulaanbaatar, Mongolia

Email: lnaraa9191@gmail.com

How to cite this paper: Naranchimeg, L., \& Enkhamgalan, Ch. (2020). Some Issues of Financial Stability Analysis. iBusiness, 12, 140-149.

https://doi.org/10.4236/ib.2020.124010

Received: November 10, 2020

Accepted: December 11, 2020

Published: December 14, 2020

Copyright $\odot 2020$ by author(s) and Scientific Research Publishing Inc. This work is licensed under the Creative Commons Attribution International License (CC BY 4.0).

http://creativecommons.org/licenses/by/4.0/

\begin{abstract}
One of the key areas of the Corporate Social Responsibility is considered ensuring financial stability that needs to be adjusted to the organizational goals. Regarded as the competency, financial stability must be considered as the prime objective to increase income to the certain level and enhance market potentials. Moreover, it is essential to determine theoretical and practical tendencies to apply the financial stability assessment of enterprises. The study was conducted on the optimal structure of capital resources and the possibility of using them in management decision-making by estimating some indicators of financial stability. We analyzed content analyses of some theoretical and methodological approaches to assess financial stability of an enterprise and estimated an effective structure study of assets and sources as indicators of financial stability in company.
\end{abstract}

\section{Keywords}

Financial Stability, Structure of Asset and Its Sources and Its Equilibrium, Financial Stability Indicators

\section{Introduction}

One of the objectives of Mongolian Sustainable Development is defined as the economic stabilization. The development policies of macro economies and other sectors have been determined to supply economic sustainability and the objectives to enhance long-term economic average growth have been put forward. Financial information helps its decision makers use financial information to cash flows for making decisions. Researcher financial statements in companies provide main evidences and facts related to company's development. The study is concluded that understanding financial statement analysis provides that it is very important to those who have the businesses as tools for reducing the considerable risks involved in starting and growing the business. The lack of financial information to the users can cause non-effective investment decisions and effec- 
tive financial statements are getting more and more required in commercial banks (Rwemalika, 2013). Financial states of enterprises, where national wealth is created and the initial financial allocation is conducted, are regarded as the base for economic stabilization. The economic, especially, the financial stability of the business sector can be determined as the provision of economic stabilization growth disabling business potential risks in the sector. Financial stability describes the equality ratio of assets and sources and is differed from the concept of solvency, which assesses current asset and short-term liability states of entities. Thus, in this paper, we aim to study the possibilities of easing management decision process by estimating effective structure study of assets and sources and some indicators of financial stability. We use the data of "XXX" company covering years of 2017-2019.

\section{Data and Methodology}

In order to assess the structure and properties of asset and sources and indicators of financial stability, we have used the data and additional disclosure of the $4^{\text {th }}$ quarter of 2017, 2018, 2019 financial statements of "XXX" company. Moreover, the data of E-balance of Ministry of Finance of Mongolia was used to estimate average indicators of the sector.

In the case of XXX, the debt ratios are generally lower than the industry average and theoretical levels (Table 1).

In order to consider the research, the related analysis and conclusions in a close connection with internal and external business environment the data collection method, the comparison method, the sample collection method and the method of average mean estimation have been used.

In addition, to determine the effective structure of asset sources mathematical methods, conventional financial analysis methods and modern computer methods have been widely employed.

\section{Financial Stability Analysis}

\subsection{Company Financial Stability States}

We have entered the XXI century and as a result we have been closer to each other. At the same time, all countries in the globalization period have aimed to implement "The Concept of Sustainable Development", the overall goal of which

Table 1. Financial indicators.

\begin{tabular}{ccccc}
\hline Estimation & Meaning & Coeff. & Sector average & XXX company average \\
\hline Financial stabilization & $\geq 0.5$ & $\mathrm{~K}_{1}$ & 0.37 & 0.33 \\
Solvency & $\geq 2$ & $\mathrm{~K}_{2}$ & 1.18 & 0.61 \\
Debt ratio & $<1$ & $\mathrm{~K}_{3}$ & 1.69 & 2.07 \\
Asset turnover & $\geq 0.6$ & $\mathrm{~K}_{4}$ & 0.45 & 0.18 \\
Effectiveness & $\geq 0.1$ & $\mathrm{~K}_{5}$ & 1.48 & -0.02 \\
\hline
\end{tabular}


is the long-term stability of the economy and environment; this is only achievable through the integration and acknowledgement of economic, environmental, and social concerns throughout the decision-making process. The appreciation of our natural resource constraints is also in our best interest. Truly rational and "effective governance requires a nation to consider and protect the environment and natural resources on which its current and future development depend. Any other approach is self-defeating. The connections between the environment and development thus provide a powerful rationale for environmental protection: enlightened self-interest" (Dernbach, 1998: p. 20). However, currently, there is a growing tendency of increasing ecological processes and changes, instigated by the negative impacts of human activities. The sustainable development is determined by the principle in which from the social sphere human is obliged to supply their own needs, fitted to the ecosystem capacity. Specific meaning of the Sustainable Development applies to the ecological concept; however, the general meaning of it characterizes modern forms and processes, directed to pursue the fundamental changes in historical orientations of civilization existence in all spheres (economic, social, ecological).

"The Sustainable Deleopment-2030" was first initiated at the United Nations Conference on Sustainable Development-or Rio+20-took place in Rio de Janeiro, Brazil on 20-22 June 2012. The goal of the Sustainable Development is the continuity of Millennium Development goals (mDgs), which implementation ended in 2015.

The General Assembly of the United Nations opened its seventieth session on 15 September, and approved 17 goals and 169 objectives of "The Sustainable Development Goals". The official worldwide implementation of SDG started in force from 1, January 2016.

The implementation of Mongolia sustainable development Vision was approved in 2016 which states "By 2030, Mongolia aspires to be amongst leading middle-income countries based on per capita income. It hopes to be a multi-sector stable economy, and a society dominated by middle and upper-middle income classes, which would preserve ecological balance, and have stable and democratic governance" (Kammaev, 2000).

Sustainable development objectives of Mongolia:

- Sustainable economic development;

- Sustainable social development;

- Environmental sustainability.

The sustainable economic development objective determines implementation of macroeconomic policy principles and principles for sectoral development.

The concept of sustainability from social development dimension is explained in modern economic literature in two fundamental levels:

1) Sustainability at Macroeconomic level (sustainability of economic systems);

2) Sustainability at Microeconomic level or company's financial stability.

Company's financial stability is determined by the indicators of equality of financial assets and resources. The system is considered stable "if the internal con- 
flict can be regulated without submerging legitimate risksx". Economic stability is defined as "a condition in which proper, effective actions are supported to finance itself in normal external environment" (Peng, 2017). Sustainability is defined in "Mongolian Sustainable Development Programme for the 21 centuries" as "the society can be assessed as stable when sources of economic resources are provided with long-term, reliable interrelations; economy sees stable growth; output (especially, labor productivity) is increased continually; and proper, fair competitive business environment is set up". Financial stability can be more broadly defined as "a condition in which the financial system can facilitate real economic activities smoothly and is capable of unravelling financial imbalances arising from shocks". Generally, financial stability can be understood as the reliable state of financial system of the country.

"It can be a shift from the economic model, prevailed in inactive form, and method to provide economic development to the steadfast method of the implementation of the investment policy in development" (Laitinen, 2018). Economic growth is measured by the changes of the real GDP per capita. However, economic development is broader concept in terms of significance than economic growth.

The financial stability of the micro level or enterprise is the proper amount of asset resources that can be dealt to implement the objectives to increase the income and accumulate the capital in order to assure liquidity in the normal situation of the arisen risks (Berthilde \& Rusibana, 2020). The financial stability is differed from the concept of liquidity, which is intended to assess the states of current assets and liabilities by showing the equal ratios of assets and resources. Considering properly the resources, put into the accumulation of fixed assets and material resources are regarded the principle condition to regulate and transform the actions, directed to improve financial state and to provide financial stability. On the other hand, company financial stability is the process to provide effectiveness of commercial and production process by utilizing resources properly; to strengthen financial performance and to provide production capacity adjusted to the social development. Enhancing financial stability implies the mobilization of capacity to implement the strategical goals. The former Secretary-General Kofi Annan addressed to the International Conference on Financing for Development organized on 2002 in Mexico "Unless we mobilize the considerable amount of financing from state and business sectors, our programme for poverty alleviation and speeding the development will be the programme stuck on the paper".

Another market requirement implies enterprises shall conduct sustainable, competition-tolerance activities, adjusted the situation to extent the effective level with their sales amounts, production capacity and financial management level. At the company level it should become the base of the financial stability since national wealth is produced and accumulated at the level of financial system.

Finance describes the structure of asset and sources. Financial stability also can be defined as the stable level of the financial state of an organization, assured 
by the percentage of equity capital in the total sources of financing.

At the enterprise level, national wealth is produced and distributed throughout the financial system, which is the basis for financial stability. Therefore, the financial stability of an enterprise is the foundation of a country's economy. Nowadays, financial stability is studied in the following areas.

Financial stability is:

- Object of management;

- The purpose of the organization;

- The main determinant of the internal environment in business;

- Development factors;

- Security assurance.

Financial stability can be understood in broad terms not only as the management object, the proper amount of asset and sources, the complex state of resource elements, organizational objectives, but also the main determiner of internal environment, development factor determining the future of the organization, safety and the criterion of possible financial risks. Financial stability is the base for implementing the sustainable development and the capability to strengthen financial states and carry on its activities continuously existing regardless of negative external factors and domestic alteration and utilizing resources properly (State Great Hural of Mongolia, 2016).

One part of the analysis of financial stability is to study the equilibrium of structure of assets and resources. Therefore, it is more crucial to estimate the structure of asset and its resources, financing opportunities for assets for enterprises.

\subsection{Asset and Source Financing Analysis}

In the market economy an organization conducts its activities by financing itself; however, if the resource is not sufficient, the method to mobilize external resources, is taken place. Accumulating own financial resources and enhancing liquidity of its assets has been the fundamental requirement of the market. One of the directions to assess financial stability is regarded as the determination of sources of financing of current assets and material resources, and the sufficiency of them. Some researchers have proposed the efficient structure of financing of asset sources in the ways (Table 2) (State Great Hural of Mongolia, 2016; Naranchimeg, 2010).

Due to business extension, the external financial involvement is increased and it urges to proper placement and the finance turnover. We have taken as an example, 2017-2019 financial statements of "XXX" company, specializes in mining industry.

In regard to XXX company, we have estimated that on 2017-2019 yearly average 43 percent of the total asset accounted for the current assets, 57 percent accounted for the non-current assets, and 55 percent of the total sources was financed by the external sources, 45 percent was financed by the equity capital of shareholders (Table 3 ). 
Table 2. Possibilities of asset financing.

\begin{tabular}{|c|c|c|c|}
\hline \multirow{2}{*}{ Asset types } & \multicolumn{3}{|c|}{ Possibilities of asset financing } \\
\hline & Innovative (A) & Agerage (B) & Conventional (C) \\
\hline \multirow{2}{*}{ Non-current assets } & $40 \%-\mathrm{LtL}$ & $20 \%-\mathrm{LtL}$ & $10 \%-\mathrm{LtL}$ \\
\hline & $60 \%-\mathrm{OC}$ & $80 \%-\mathrm{OC}$ & $90 \%-\mathrm{OC}$ \\
\hline \multirow[b]{2}{*}{ Fixed parts of Current assets } & $50 \%-\mathrm{LtL}$ & $25 \%-\mathrm{LtL}$ & \multirow[b]{2}{*}{$100 \%-\mathrm{OC}$} \\
\hline & $50 \%-\mathrm{OC}$ & $75 \%-\mathrm{OC}$ & \\
\hline \multirow{2}{*}{ Variable parts of Current assets } & \multirow[b]{2}{*}{$100 \%-S t L$} & \multirow{2}{*}{$100 \%-S t L$} & $50 \%-\mathrm{OC}$ \\
\hline & & & $50 \%-S t L$ \\
\hline
\end{tabular}

LtL-Long-term obligations; StL-Short-term obligations; OC-Equity capital.

Table 3. Structure of asset and sources (\%) /XXX company/.

\begin{tabular}{cccccc}
\hline Indicators & 2017 & 2018 & 2019 & \multicolumn{2}{c}{$2017-2019$ year average } \\
\cline { 5 - 6 } & & & & u/weight & growth, \% \\
\hline Current assets & 26.6 & 15.6 & 16.5 & 43.0 & 102.0 \\
Non-Current assets & 73.4 & 84.4 & 83.5 & 57.0 & 138.1 \\
Total asset & 100.0 & 100.0 & 100.0 & 100.0 & 129.5 \\
Short-term obligations & 29.4 & 28.0 & 19.8 & 35.2 & 81.4 \\
Long-term obligations & 31.4 & 28.3 & 36.2 & 19.8 & 103.6 \\
Total liabilities & $\mathbf{6 0 . 8}$ & $\mathbf{5 6 . 3}$ & $\mathbf{5 6 . 0}$ & $\mathbf{5 5 . 0}$ & $\mathbf{9 3 . 8}$ \\
Equity capital & 39.2 & 43.7 & 44.0 & 45.0 & \\
Total sources & $\mathbf{1 0 0 . 0}$ & $\mathbf{1 0 0 . 0}$ & $\mathbf{1 0 0 . 0}$ & $\mathbf{1 0 0 . 0}$ & $\mathbf{1 2 9 . 5}$ \\
\hline
\end{tabular}

Let's do the valuation of structure of assets and sources, shown in Table 1, based on the innovative (A) possibility.

Table 4 shows the result that the total debt will be 56 percent and the equity will be 44 percent for optimal structure for the "XXX" company:

\begin{tabular}{lccc}
\hline \multicolumn{1}{c}{ Indicators } & Short-term liabilities & Long-term liabilities & Equity capital \\
\hline $\begin{array}{l}\text { 1. Valuated by 2017-2019 yearly } \\
\text { average }\end{array}$ & 35.2 & 19.8 & 45.0 \\
\begin{tabular}{l} 
2. Valuated by Innovative /A/ model \\
\hline
\end{tabular} & 19.0 & 35.0 & 46.0 \\
\hline
\end{tabular}

The estimation of asset and finance /XXX company/:

\begin{tabular}{lll}
\hline 1. Non-current assets & $57 \% \times 0.4=0.23 \mathrm{LtL}$ & \\
& $57 \% \times 0.6=0.34 \mathrm{OC}$ & $44 \%-\mathrm{OC}$ \\
& $20 \% \times 0.5=0.1 \mathrm{LtL}$ & $33 \%-\mathrm{LtL}$ \\
2. Fixed parts of Current assets & $20 \% \times 0.5=0.1 \mathrm{OC}$ & $23 \%$-StL \\
& $23 \% \times 0.1=0.23 \mathrm{StL}$ &
\end{tabular}


Table 4. The structure of asset and finance /XXX company/.

\begin{tabular}{|c|c|c|c|c|}
\hline Asset types & $\begin{array}{l}\text { \% Valuated by } 2017- \\
2019 \text { yearly average }\end{array}$ & $\begin{array}{l}\text { Asset financing } \\
\text { possibility (A) }\end{array}$ & $\begin{array}{l}\text { Financing } \\
\text { involvement }\end{array}$ & $\begin{array}{l}\text { Financing } \\
\text { structure }\end{array}$ \\
\hline \multirow{2}{*}{ Non-current assets } & \multirow{2}{*}{0.57} & $0.4-\mathrm{LtL}$ & $0,23-\mathrm{Ltl}$ & \multirow{4}{*}{$\begin{array}{l}44 \%-\mathrm{OC} \\
33 \%-\mathrm{LtL} \\
23 \%-\mathrm{StL}\end{array}$} \\
\hline & & $0.6-\mathrm{OC}$ & $0.34-\mathrm{OC}$ & \\
\hline \multirow{2}{*}{ Fixed parts of Current assets } & \multirow{2}{*}{0.2} & $0.5-\mathrm{LtL}$ & $0.10-\mathrm{LtL}$ & \\
\hline & & $0.5-\mathrm{OC}$ & $0.10-\mathrm{OC}$ & \\
\hline Variable parts of Current assets & 0.23 & $1.0-\mathrm{StL}$ & $0.23-\mathrm{StL}$ & \\
\hline Total & 1 & & & 1 \\
\hline
\end{tabular}

Even though 55 percent of the total financing of the company was compensated by the liabilities, there was a tendency of prevalence of short-term obligations due to the insufficient availability of external sources, especially long-term finance to provide business investment growth. We have estimated the asset finance by the innovative model, the equity capital and long-term obligations involvement was shown in increase, while short-term credits, liability involvemen in decrease.

\subsection{Indicators of Financial Stability}

As we discussed in the previous section, one of the key areas for corporate financial stability is the equilibrium of structure of assets and resources. Therefore, it is more crucial to estimate the structure of asset and its resources, financing opportunities for assets for enterprises. As shifting to the optimal structure of asset financing the size of debt increases that is due to the condition of market economic. An increase in the amount of debt and a decrease in the amount of equity directly affect the estimation of key indicators of financial stability.

To valuate Financial Stability there are modern analytic methods such as ABC types of asset, source structure method, the state that provides 5-angles or pentagons, the state that might lead to financial difficulties, and rating estimation method (Naranchimeg, 2020).

We have chosen the following 5 indicators from the main indicators, used to do financial stability analysis; they are shown in the form of pentagon on the example of XXX company.

In the case of XXX, the debt ratios are generally lower than the industry average and theoretical levels (Table 5).

The state of financial stabilization $\left(K_{1}\right)$ was estimated by independence ratio. The independence ratio determines the percentage of equity capital in the total assets and is defined as accurate if meaning coefficient accounts for not below 60 percent (National conference on Economy and Business Study, 2013; Savitskaya, 2006).

Solvency $\left(\mathrm{K}_{2}\right)$ was estimated by the current ratio. The current ratio is a liquidity ratio that measures a company's ability to pay short-term obligations 
Table 5. The states of financial stabilization.

\begin{tabular}{ccccc}
\hline Estimation & Meaning & Coeff. & Sector average & XXX company average \\
\hline Financial stabilization & $\geq 0.5$ & $\mathrm{~K}_{1}$ & 0.37 & 0.33 \\
Solvency & $\geq 2$ & $\mathrm{~K}_{2}$ & 1.18 & 0.61 \\
Debt ratio & $<1$ & $\mathrm{~K}_{3}$ & 1.69 & 2.07 \\
Asset turnover & $\geq 0.6$ & $\mathrm{~K}_{4}$ & 0.45 & 0.18 \\
Effectiveness & $\geq 0.1$ & $\mathrm{~K}_{5}$ & 1.48 & -0.02 \\
\hline
\end{tabular}

(Rwemalika, 2013). This ratio measures a company's ability to pay short-term obligations and is defined as accurate if the meaning accounts for not below 2 .

The debt ratio $\left(\mathrm{K}_{3}\right)$ is defined as the ratio of total debts to the equity capital, expressed as a decimal or percentage. It can be interpreted as the proportion of a company's assets that are financed by debt. It is defined as accurate if the ratio is not above 1 (Sainjargal \& Bat-Ulzii, 2000; Sainjargal et al., 2020).

The asset turnover $\left(\mathrm{K}_{4}\right)$ ratio measures the value of a company's sales or revenues relative to the value of its assets. The asset turnover ratio can be used as an indicator of the efficiency with which a company is using its assets to generate revenue. We define it as accurate if the ratio is not less than 0.6.

Effectiveness $\left(K_{5}\right)$ is implied by the net income amount accounted for unit of asset and we regard it to be not less than 10 percent.

As the performance meaning of the above 5 indicators increases and is near to the accurate level of the theory (figure extends), this implies that all financial performances of a company are relatively in good position. The chosen 5 indicators to provide the proper theoretical meaning indicate uneven, or poor performances. In the case of "XXX" company, the average meaning stays below the theoretical meaning, or not sufficient for 5 angles, or pentagon it is evident from Figure 1. As for the indicators of Financial Stabilization $\left(K_{1}\right)$ the performance has been estimated around 60 percent, the indicators such as, solvency ratio $\left(\mathrm{K}_{2}\right)$, asset turnover $\left(\mathrm{K}_{4}\right)$, effectiveness $\left(\mathrm{K}_{5}\right.$, unprofitable) have been at relatively low level, debt ratio $\left(K_{3}\right)$ indicates 2 times higher. Thus, the indicator impacted the financial stabilization level to be occurred.

In order to strengthen the financial stabilization, it is essential to pay close attention not only to any of the indicators, but also to the complex indicators, especially, to the return on invested asset (since it becomes the base of provision of equity capital growth) financing structure and solvency criterion. Moreover, it is required to use them in management decision-making process.

\section{Conclusion}

It is required to define the entities as the core of the economic and financial stability and the base of the market relation development, since any product, service, national wealth, income and output is created at entities and organizations and the income is distributed through initial and re-allotment to society, community, employees, and investors. 


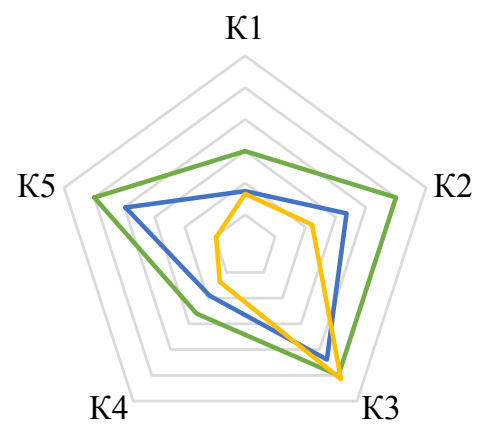

- Meaning - Sector average - XXX company average

Figure 1. The state of financial stability.

As a result of the "XXX" company, although 55\% of total financing is covered by the amount of debt, short-term loans and liabilities dominate due to insufficient availability of external sources, including long-term financing to ensure the growth of business investment.

Under our new asset financing structure, the estimation shows the result that the amount of equity and long-term loans will be increased, and the amount of short-term loans will be decreased. In order to ensure financial stability, it is necessary to take a complex approach, not just one; the more one is to pay equal attention to the return on investment (as it will be the basis for equity capita's growth) to meet the criteria for capital and funding structure and solvency.

Financial stabilization must be seen not only through the process and output, but also through organizational objectives, their implementation, timing and the factors that influence the result. From this point we can conclude that financial stability can be defined as:

- Organizational priority goal;

- Chances of the goal implementation;

- The core management object.

\section{Conflicts of Interest}

The authors declare no conflicts of interest regarding the publication of this paper.

\section{References}

(2013) National Conference on Economy and Business Study (p. 250). Ulaanbaatar.

Berthilde, M., \& Rusibana, C. (2020). Financial Statement Analysis and Investment Decision Making in Commercial Banks: A Case of Bank of Kigali, Rwanda. Journal of Financial Risk Management, 9, 355-376. https://doi.org/10.4236/jfrm.2020.94019

Dernbach, J. C. (1998). Sustainable Development as a Framework for National Governance. Case Western Reserve Law Review, 1-103.

Kammaev, A. O. (2000). The Methodological Basis of Managing Financial Stabilization in the Construction Sector (p. 14). 
Laitinen, E. (2018). Financial Reporting: Long-Term Change of Financial Ratios. American Journal of Industrial and Business Management, 8, 1893-1927.

https://doi.org/10.4236/ajibm.2018.89128

Naranchimeg, L. (2010). The Theory and Practice of Financial Stabilization Analysis. Ulaanbaatar.

Naranchimeg, L. (2020). The Study and Survey on Consolidated Financial Statements of Mongolian Entities. Ulaanbaatar.

Peng, H. L. (2017). Analysis on Financial Support of the Development of China's Economic Transformation in a New Situation. Business \& Economics, 8, 249-255.

Rwemalika, E. (2013). Financial Statements Analysis and the Performance of Commercial Banks in Rwanda: A Case Study of Bank of Kigali.

Sainjargal, B., \& Bat-Ulzii, J. (2000). The Study of Financial Capacity of Business Entity 1996-2000. Project Report.

Sainjargal, B., Naranchimeg, L., Khurelbaatar, B., \& Chimedsuren, C. (2020). Financial Situation Analysis of Entities. iBusiness, 12, 1-12. https://doi.org/10.4236/ib.2020.121001

Savitskaya, G. B. (2006). The Methodology of Complex Analysis of Economic Activities (p. 270). Moscow.

State Great Hural of Mongolia (2016). Mongolia Sustainable Development Vision 2030. 